\title{
The impact of experiential learning on Environmental Education during a Moroccan summer university
}

\author{
Malak Bouhazzama ${ }^{1, *}$ and Said Mssassi ${ }^{1}$ \\ ${ }^{1}$ National School of Management, Management Department, Tangiers, Morocco
}

\begin{abstract}
In this study, the goal is to explore the impact of Experiential Learning Theory (ELT) and different experiential approaches on learning about sustainable development in environmental experiential learning education. Teachers were involved in participation with students to enhance their understanding of the importance of environment, developing their aptitude to combine theory and practice, also expanding their global vision. In order to accomplish this project with original learning opportunities, qualitative data of thirty participators was collected and revealed important issues in terms of pedagogical methodology in applying this theory. Overall, this paper shows the great capacity of learners to identify their styles and modes of learning and to expand them in all disciplines and fields even in their personal usual or professional life in the future and proposes global innovations in Moroccan environmental education.
\end{abstract}

\section{Introduction}

This paper is positioned at the intersection of the three key areas: the experiential learning, the sustainable development and the environmental education. We view learning as a social and cultural process and attempt to demonstrate in this paper that teachers expertise should not only reside in the knowledge domains typically established by universities and schools. Another crucial knowledge domain that should be accessible to all preservice teachers is the community and we argue that universities, schools and community partners stand as key knowledge bases that when combined can maximize the learning potential of beginning teachers today. For facilitating the transition to sustainability in Morocco we have to think about: 1) strengthening higher education institutions capacity for educating young professionals in environmental education and sustainable development (SD), 2) assisting students in universities in understanding and implementing EL and SD strategies in their respective organizations, and 3) creating an innovative method in collaboration across partner institutions, countries and the public (Ashton et al., 2016).

Experiential learning theory (ELT) has been in ample employment in education and study for plural years, however it has not been frequently used in general practice in the environmental field. In this part, we propose a summary of the various doctrines and theories of ELT. As defined by Kolb, EL is the affirmation that people learn within explorations and experiences that form the process of knowledge and transform our cognitive development. Experience is an activity, it relates to the manners by which learners study and apply on private experience, experience implies openly engage in various activities Clark (2010) by applying knowledge reached through private life. In ELT, Learners transform the experience earned during the learning activity to a fundamental frame of their lives; this remodeling affects their emotions and attitudes inciting more attention on external behaviors. The experiential learning cycle illustrates a descriptive mechanism of how knowledge is created through the transformation of experience. This conversion consists of four stages in learning and corresponds to four learner styles. As we noticed based on the theory of Kolb, the experiential learning cycle includes four stages that the learner migrates through immediate or concrete experiences to produce a base for remarks and reflections which are consequently received and understood with past knowledge and transcribed into theoretical concepts which then provide to be tested and examined moreover in new experiences.

\section{Experiential learning}

The experiential learning cycle includes two major dimensions of learning perception and processing. Each dimension specified different modes of learning that mutate between a real experience and conceptual context from active experimentation to reflective observation. Synchronically, the four stages of learning form a fourquadrant field for diverse learning styles, particularly: accommodating, divergent, assimilating, and converging as defined bellow:

- Concrete Experience (CE) describes the joining aspects of the examined phenomenon for studying problems and solutions. While a learning situation, the scholar develops his ability to be receptive and flexible to adapt.

* Corresponding author: malak.bouhazzama.doctorat@gmail.com 
- Reflective Observation (RO) permits students to learn ideas from various opinions. Learning to proceed by viewing or listening and then sentiments to form conclusions.

- Abstract Conceptualization (AC) includes studying by thinking the scholar forms hypotheses and examination of ideas to explain positions based on emotions.

- Active Experimentation (AE) permits learning by performing by active synergy and experimentation in relation to the topic of study. The learner uses pragmatic learning and cannot evidently receive information or obeying a situation.

In Experiential learning theory Kolb (2005) identifies four learning styles that match many combinations of the experiential learning modes cited before, these are the four learning styles:

- Accommodators who favor real experience to theory,

- Divergers who prefer to learn by collecting pertinent information and perceiving varied points of view into the study,

- Assimilators who learn more effectively by building a variety of information and classing them into a logical form

- And finally convergers who likes learning when illustrated with practical cases in finding solutions to real problems.

Nevertheless, we all apply a mixture of styles at various moments but each scholar has a dominant learning style but the perfect way to learn is to develop the ability to combine the four styles with maturity and in a professional way. As seen before, experiential learning proposes a valuable framework permitting learners to cooperate with their learning environment and to improve their learning by examination, reflection, investigation, and synthesis

\subsection{Education and experiential learning}

The symbiosis between education and experiential learning is not a new theory. As the father of this concept, Dewey (1897) stated a pedagogical model focused on research, experience and progression. Nowadays, experiential learning is compulsory in education to construct knowledge and build new activities based on experience. The aim of this study is to demonstrate the impact of experiential learning on environmental education by two research questions: 1) How do students at Summer University apply the theory of experiential learning in environmental education as determined by Dewey and Kolb, and 2) How do teacher perceive this learning method to link environment and sustainable development?

\subsection{Education and Sustainable development}

According to Dlouha and Burandt (2015), universities require accommodating multidisciplinary and interdisciplinary education. For illustration, Sustainability in environmental education as a transdisciplinary subject is managing competencies as issues and evaluations and student's attitudes as indications for practice. The intention of this experience is to change the communication processes between professors or teachers and students in order to amplify interactions to promote self-directed education. This study describes how students can be practiced sustainability by injecting the concept of sustainable practice in environmental education.

For Lozano (2010), learning sustainability in the university needs to be developed into a participative process with possibilities for students to experience a more dynamic and interactive approach. In order to develop this mutual approach of learning and teaching, we need more social synergy and modification of pedagogical goals and outcomes with converging on competencies to immigrate from a traditional communication model to an interactive one. Zhang et al. (2012) discussed how to change standards around SD and to develop sustainability competencies by specific educational approaches promoting knowledge and teaching materials and methods about sustainability. By competencies we mean the capacity to communicate, learn and solve problems effectively with students by acting in favor of sustainable development and finally capacity to operate between technological, ecological, human, and ecological elements" (Pearce and Ahn, 2010). According to Pearce and Ahn (2010), the main challenge in education in SD is to admit studying that defeats through traditional limits. Nevertheless, Ashford (2004) defines this challenge as the empowerment of students to investigate new perspectives approach as seen on the table1.

Table 1. List of examined studies on popular teaching methods for sustainability subjects.

\begin{tabular}{|l|l|l|}
\hline Authors & $\begin{array}{l}\text { Methods of } \\
\text { teaching } \\
\text { sustainability }\end{array}$ & $\begin{array}{l}\text { Characteristics } \\
\text { of Methods }\end{array}$ \\
\hline $\begin{array}{l}\text { Brundiers } \\
(2013)\end{array}$ & $\begin{array}{l}\text { alliances between } \\
\text { universities and } \\
\text { private organizations } \\
\text { as for leading } \\
\text { learning courses in } \\
\text { sustainability }\end{array}$ & $\begin{array}{l}\text { Combining } \\
\text { learning } \\
\text { objectives and } \\
\text { practical } \\
\text { experience }\end{array}$ \\
\hline Du et al. (2013) & $\begin{array}{l}\text { Promoting skills } \\
\text { connected to } \\
\text { sustainability }\end{array}$ & $\begin{array}{l}\text { culture and } \\
\text { environmental } \\
\text { obligations }\end{array}$ \\
\hline $\begin{array}{l}\text { Papaoikonomou } \\
(2016)\end{array}$ & $\begin{array}{l}\text { promote learners' } \\
\text { knowledge and } \\
\text { perspectives }\end{array}$ & $\begin{array}{l}\text { macro level, } \\
\text { curricula level, } \\
\text { and instrumental } \\
\text { level }\end{array}$ \\
\hline
\end{tabular}

\subsection{Emotion and experiential learning}

At this stage of the study, it's compulsory to talk about three related concepts in ELT: mood that relates to the short duration, affection referring to a long-term and general state of mind of mood, and emotion connecting to a constant emotional reaction formed in a specific position, location and situation. Emotion comes from personal experience; such information is usually combined with mental and psychological events that are 
caused by a mixture of thinkings, feelings, and reactions (Kellerman, 2003). Furthermore, many psychoanalysts have developed the emotional influence of learning behavior physiological and psychological feedback (Maier, 2006), positive emotion as an inclination to ease and comfort, meaning that when somebody experiences positive emotion, he is more likely to see encircling people with a comfortable state of mind. So, positive emotion amplifies learning while negative emotion can defeat learning (Pekrun, 2000). According to preceding findings, this study describes learning emotions as positive (calm, comfortable, content, positive, emphatic, and confident) and negative (tired, worried, pessimistic, anxious, annoyed, and angry). In this study, we're going to register the learning emotions of students to discover learners' emotional processes in environmental educational as seen on table2.

Table 2. Comparison of learner's emotions on the beginning and the end of the study

\begin{tabular}{|c|c|c|c|}
\hline Cycle & $\begin{array}{c}\text { First } \\
\text { course } \\
\text { Emotions }\end{array}$ & $\begin{array}{c}\text { Last course } \\
\text { Emotions }\end{array}$ & $\begin{array}{c}\text { Global } \\
\text { Appreciation } \\
\text { of teacher }\end{array}$ \\
\hline $\begin{array}{c}\text { Environmental } \\
\text { education }\end{array}$ & Negative & Positive & $70 \%$ \\
\hline $\begin{array}{c}\text { Experiential } \\
\text { learning }\end{array}$ & Negative & Positive & $85 \%$ \\
\hline $\begin{array}{c}\text { Sustainable } \\
\text { development }\end{array}$ & Negative & Positive & $100 \%$ \\
\hline
\end{tabular}

\section{Methods}

In order to permit learners to become involved in environmental education, this research revealed a specific learning model using the model of Kolb's experiential learning cycle (Kolb, 1984): concrete experience, reflective observation, abstract conceptualization, and active experimentation. In order to permit learners to become involved in environmental education, this research revealed a specific learning model using the model of Kolb's experiential learning cycle (Kolb, 1984): concrete experience, reflective observation, abstract conceptualization, and active experimentation. Moreover, based on the emotions of learners, this method presents two roles in experiential actions: the first one is to assist learners to understand the environmental education in heart of sustainable development to enrich the educational meaning of the environment and the second is to strengthen the impact of exploratory learning methods to identify their appropriate style and mode of experiential learning. We can see clearly on the table an illustration of the impact of emotion on learning while using experiential learning in environmental education to explain sustainable development. To recognize the influence of the method on emotion and learning impact in the environmental education context, this research conducts an assessment post courses in the summer university within a week in Morocco.
The learners were thirty youth students: 15 Males and 15 Females, 65\% are studying in Moroccan universities and most of them are females, their age is between 18 and 35 years old; $75 \%$ are aged between 18 and 25 years old. The presentation took daily two hours in the morning, two in the afternoon, and three hours at night for one week. Generally, we used a PowerPoint presentation with simple materials including pictures, videos, and sounds to help the scholars finding their specific style of learning. The data was collected after a month of familiarization with the research literature and preparation for the workshops. After this observation period, many seminars were organized during the summer university following the experimental learning model with thirty young people as follows:

- A first phase of teaching allowing each learner indirectly to recognize their learning style through presentations, questioning as they go, a post-evaluation of the content of the seminar and learning methods without forgetting the video recording which was analyzed properly which allowed the learner to know his own style and mode of learning. During this phase, most of asked questions are related to the evaluation of seminars as did you assimilate the concept of sustainable development? What is the link with the environmental education?

- A second phase which is a phase of conceptualization and application of the experiential learning cycle where the learner recognizes his own learning style. Then, a hot assessment was planned for the benefit of twenty learners in the form of a qualitative study through semistructured interviews. The interviews lasted 30 to 45 minutes with the learners in order to assess this new learning cycle for them and ended at their will. Indeed, the participants were ready to exchange and found no difficulty in expressing themselves and shared their experiences willingly and with ease. At this level, we ask participant more about his assimilation of experiential learning. What is the cycle of experiential learning? Do you recognize your style of learning?

\section{Results and discussion}

In this study, the goal is to explore the impact of ELT and different experiential approaches on learning about sustainable development in environmental experiential learning education. The data gathered after the selfassessment interview and based on many discussions and recommendations after all courses was the base to evaluate:

-The impact of this specific learning tool on emotions.

-The performance of experiential learning theory and the learning effectiveness on teaching environmental education especially to sustainable development.

-The capacity of learners to identify their styles and modes of learning and to develop them to learn in all disciplines and fields even in their personal usual or professional life in the future.

Indeed, all of the learners appreciated the experimental learning and admit to having correctly assimilated the content of courses and learned for the 
first time at $100 \%$ about environmental education and sustainable development especially from the second course since they begin to recognize their learning style. Even more, they unanimously found ideas to promote environmental education, $80 \%$ of which decided to embark on experiential learning theory in their studies and work and $20 \%$ joined forces to make social actions to protect the environment. Some have even proposed to develop further experiential learning techniques for better understanding based on their learning style. So, they were not only were they seduced by environmental education but having a long-term vision respecting the principles of sustainable development.

One scholar noted, "I believe that joining this summer university changes a lot on me as a student, it changed the concept of learning, I wish we can apply this model in our universities!" another one said, "These courses make me see my future better as a student." All those positive emotions promoted this learning model and lighten the psychological burden for students. The study admits some imperfections due to time and financial constraints, the experimental duration was only one week if extended it will provide more synergy between scholars and the learning context (Goleman, 2001). Believing that all learners aren't able to learn in an identical manner so educators need to develop and perform alternative teaching techniques (Muthukrisma et al., 1993). So using ELT won't be an easy job for students and teachers in the beginning to remodel their methods throughout the learning process (Aggelakos, 2003) by developing many skills like patience, innovation, responsibility and empathy. Certainly, there is not just one but several ways to learn. However, the challenge would be to choose the most suitable for both the teacher and the learner. In this study, the learning style was the keystone to teach environmental education, but this did not prevent this process from provoking much reflection on flexibility and patience and did not generate resistance to change. Roughly speaking, this study presented spectacular results, the center of which is experimental learning in learning about sustainable development and environmental education and leaves an opportunity for rethinking the problem of learning and teaching training.

\section{Conclusion}

Learning styles represent an important basis for environmental education allowing researchers to adapt various features of sustainable development. As affirmed by Brisson et al. (2012), user models for interactive learning do need to adapt to different user learning styles and overall preferences in a proper way. For the creation of new mode of education in Moroccan universities especially in the environmental field including the psycho-cognitive abilities and skills of the student with respect to learning, motivation, and creativity. Experiential styles can be applied for flexibly and efficiently educational methods to the intellectual abilities, personality and intrinsic and extrinsic motivations of players (Magerko et al. 2008).

\section{References}

1. J. R. Aaron, Experiential learning: Transforming strategic management to strategic business consulting. Developments in business simulation and experiential learning: Proceedings of the annual ABSEL conference. Vol 45. (2018).

2. D. Diaz Granados, Improving the clinical learning environment: A collaborative workshop for students, residents, and faculty. (2018).

3. P. Dillenbourg, What do you mean by collaborative learning? Collaborative learning: Cognitive and computational approaches. Oxford: Elsevier1-19. (1999).

4. K. Fitch, Developing professionals: Student experiences of a real-client project. Higher Education Research and Development, 30(4), 491503. (2011).

5. D. A. Kolb, Experiential learning: Experience as the source of learning and development. FT Press (2014).

6. A. Y.Kolb, \& D. A. Kolb, Experiential learning theory: A dynamic, holistic approach to management learning, education and development. The SAGE handbook of management learning, education and development 42-68. (2009).

7. M.Lehmann, P.Christensen , M. Problem-oriented and project-based learning (POPBL) as an innovative learning strategy for sustainable development in engineering education. European Journal of Engineering Education, 33(3), 283-295. (2008).

8. E. Anderberg, B.Nord, B.Hansson, Global learning for sustainable development in higher education: recent trends and a critique. Int. J. Sustain. High. Educ. 10 (4), 368e378.(2009).

9. N.Ashford, Major challenges to engineering education for sustainable development. Int. J. Sustain. High. Educ. 5 (3), 239e250.( 2004).

10. D.A.Kolb, Experiential Learning: Experience as the Source of Learning and Development, first Ed. Prentice Hall, New Jersey, p. 41.( 1984).

11. A. Kolmos, F.K.Fink, The Aalborg PBL Model: Progress, Diversity and Challenges. Aalborg University Press, Aalborg, pp. 9e15.( 2004).

12. T.Lans, V.Blok, Wesselink, R., Learning apart and together: towards an integrated competence framework for sustainable entrepreneurship in higher education. J. Clean. Prod. 62, 37e47.( 2014).

13. M. Lehmann, P. Christensen, , Problem-oriented and project-based learning (POPBL) as an innovative learning strategy for sustain- able development in engineering education. Eur. J. Eng. Educ. 33 (3), 283e295.(2008).

14. R. Lozano, , Diffusion of sustainable development in universities' curricula: an empirical example from Cardiff University. J. Clean. Prod. 18 (7), 637e644. (2010). 
15. J.MacVaugh, Norton, M., Introducing sustainability into business education contexts using active :learning. Int. J. Sustain. High. Educ. 13 (1), 72e87.(2012).

16. Q. Zhang, L.Vanasupa, Challenges for integrating of sustainability into engineering education. Am. Soc. Eng. Educ. AC 2012e4565. (2012).

17. K. Attard, \& K. M.Armour . Learning to become a learning professional: Reflections on one year of teaching. European Journal of Teacher Education, 28(2),195e207. (2005).

18. C. Baldwin, A. M. Buchanan \& M. E Rudisill. What teacher candidates learned about diversity, social justice, and themselves from service-learning experiences, Journal of Teacher Education, 58(4), 315e327. (2007).

19. H. Coffey, "They taught me": The benefits of early community-based field experiences in teacher education. Teaching and Teacher Education, 26, 335e342. (2010).

20. K. Brayko, Community-based placements as contexts for disciplinary learning: A study of literacy teacher education outside of school. Journal of Teacher Education, 64(1), 47e59. (2013).

21. Brinkman, S., \& Kvale, S. Interviews: Learning the craft of qualitative research interviewing. Thousand Oaks, CA: Sage. (2015).

22. J. Dewey, Experience and education. New York. NY: Collier Books. (1938).

23. Z. Gross \& S. D.Rutland, Experiential learning in informal educational settings. International Review of Education, 63, 1e8. (2017).

24. G. J. Harfitt \& Chan, C. Constructivist learning theories in teacher education programmes: a pedagogical perspective. In D. J. Clandinin, \& J. Husu (Eds.), International Handbook of Research on Teacher Education (pp. 545e561). London, UK: SAGE. Ch.31. (2017).

25. Moore, D. T. Forms and issues in experiential learning. New Directions for Teaching and Learning, 124, 3e13. (2010).

26. Baxter, P. \& Jack, S. Qualitative Case Study Methodology: Study Design and Implementation for Novice Researchers. The Qualitative Report, 13(4), 544-559. (2004).

27. D. Kolb, Experiential learning: experience as the source of learning and development. Englewood Cliffs: Prentice Hall. (1984).

28. R.K. Yin, Case study research. Design and methods (3rd edition). London: Sage (2003).

29. L. W. Anderson, D. R Krathwohl, \& Bloom, B. S. Taxonomy for learning, teaching, and assessing: A revision of Bloom's taxonomy of educational objectives. Allyn \& Bacon. (2001).

30. P. H.Anderson \& L. Lawton, The effectiveness of a simulation exercise for integrating problem-based learning in management education. Developments in
Business. Simulation and Experiential Learning, 32. (2005).

31. A. Y. Kolb \& D. A. Kolb, Learning styles and learning spaces: enhancing experiential learning in higher education. Academy of Management Learning and Education, 4, 193e212. (2005)

32. Z. Abdullah, Activity theory as analytical tool: a case study of developing student teachers' creativity in design. Procedia Social and Behavioral Sciences, 131, 70e84. (2014).

33. B. L. Fredrickson, The role of positive emotions in positive psychology: the broaden-and-build theory of positive emotions. American Psychologist, 56, 218e226. (2001).

34. J. P. Hautecoeur, Ecological education in everyday life: Alpha 2000. University of Toronto Press. (2002).

35. J. L. Plass \& U. Kaplan, Emotional design in digital media for learning: an integrated cognitive affective model of learning with multimedia (ICALM). (2015). 